\title{
Antioxidant Activity of Sausage by Seasoning Galangal (Alpina Galanga L.) and Lemograss (Cymbopogon citratus)
}

\author{
${ }^{1}$ Nurul Adha, ${ }^{2}$ Hikmah M. Aliand and ${ }^{2}$ Muhammad Irfan Said \\ ${ }^{1}$ Postgraduate of Animal Science Department, University of Hasanuddin, Makassar, South Sulawesi, Indonesia \\ ${ }^{2}$ Animal Science Department, University of Hasanuddin, Makassar, South Sulawesi, Indonesia
}

Correspondence Author: Nurul Adha, Department of Animal Science and Technology, Faculty of Animal Science, University of Hasanuddin, Makassar90245, Indonesia

Tel: 6285343848622

Received date: 23 July 2018, Accepted date: 10 October 2018, Online date: 15 October 2018

Copyright: (C) 2018 Nurul Adha et al., This is an open-access article distributed under the terms of the Creative Commons Attribution License, which permits unrestricted use, distribution, and reproduction in any medium, provided the original author and source are credited.

\begin{abstract}
Oxidation is one of the important factors that affect the quality of meat products including sausages. To inhibit oxidation, necessary to add material in the processing that act as antioxidants. One of the plants that serve as natural antioxidants is galangal (Alpina galanga L.) and lemograss (Cymbopogon citratus) because the content of flavonoids and phenols very high. This study aimed to determine the effect seasoning of galangal-lemograss(50:50\%) on the antioxidant activity of sausages. The experiment was conducted with completely randomized design with factors such as the type of seasoning (stir-fried and fresh) with the level of addition of galangal-lemograss seasonings $(0,5,10$ and $15 \%)$. The results showed that the addition of galangal and lemograss seasonings was able to increase the antioxidant activity of sausages.
\end{abstract}

Key words: Oxidation, Antioxidant, Galangal (Alpina galanga L.), Lemograss (Cymbopogon citratus), sausage.

\section{INTRODUCTION}

Sausage is a meat product which preferred by consumers. is due to taste, form and presenting sausages. Consumer preferences are influenced by the quality of ingredients, how to manufacture, storage, and presentation of the product[1,2]. Model of sausage preparation consists of two kinds of fresh and frozen[2]. Fresh sausages can be directly consumed by consumers a moment after manufacture, but can not last long at room temperature.An attempt to overcome these obstacles is to frozen storage. Frozen sausages can last long with some properties changes. All changes is frozen storage purposesexcept the changes (oxidation) of lipid [2,3].

One of the factors causing damage is the oxidation process. Oxidation of fats and proteins can cause damage to foodstuffs. Damage can be prevented by the presence of antioxidants, both natural antioxidants from food, added synthetic antioxidants and antioxidants obtained from processing activities [4]. Lipid oxidation will produce a variety of volatile compounds that caused rancid, off-flavo, high cooking lossof the product, decrease nutritional value and storage life, as well as the accumulation of some toxic compounds capable of interfering with the health[3,4]. Therefore, the oxidation should be controlled and even prevented with the use of antioxidants.

Some research suggests compounds that have the potential of antioxidants including flavonoids and phenolics. Flavonoids function neutralize free radicals thus minimizes damage to cells and tissues [5]. One of the plants that high flavonid is galangal (Alpina galanga L.) and lemograss (Cymbopogon citratus). Besides a role in preventing rancidity, antioxidants also has the potential to improve the quality of products [6.7]. Therefore, the addition of Alpina galanga L. and Cymbopogon expected to increase antioxidant activity of sausages.

\section{MATERIALS AND METHODS}

This study uses broiler chicken meat. Materials for the manufacture are seasoning (Alpina galanga L. and Cymbopogon citratus), Isolate Soy Protein, nutmeg, tapioca flour, cooking oil, salt, ice cubes, flavors ingredients (pepper and garlic). Materials for testing the characteristics and antioxidant activity DPPH solution of the sausage is $20 \mathrm{ppm}$, methanol, distilled water, and reagents TBA. The tools used in this study is a food processor, stoves, boiling pans, basins, knife, water bath, micropipette, petri dishes, blender, measuring cups, spectrophotometric, distillation equipment, and others.

The experiment was conducted using a completely randomized design with the addition of spices (Alpina Galanga L. and Cymbopogon citratus) as a treatment and three replications. The levels were $0,5,10,15 \%$ of the weight of meat. Creation phase consists the manufacture of making spices (Alpina galanga L. and Cymbopogon citratus), making sausages, and parameters test.

Seasoning of (Alpina galanga L. and Cymbopogon citratus) was prepared with 2 types of supply, namely stir-fry and fresh with a ratio of 50 : 50 with levels of $0,5,10,15 \%$.Manufacturing of meatballs phase consists of trimming, materials measurement, addition of seasonings $(0,5,10,15 \%)$, grinding, mixing the ingredients, insertion into sleeves and cooking.

DPPHtestsaims to determine the parameters concentration gives $50 \%$ effect equivalent antioxidant activity (IC50). The existence of antioxidant compounds can be determined by DPPH solution color change from purple to yellow[8].TBA numbers measurement is performed to determine the occurrence of rancidity by measuring the levels of malonaldehida formed. Measurements use rancidity intensity analysis through methods Thiorbarbituric Acid Reactive Subtances 
(TBARS). Distillate absorbance was measured at a wavelength of $528 \mathrm{~nm}$ with the blank solution as the zero point. The reference solution made of a mixture of $5 \mathrm{ml}$ of distilled water plus $5 \mathrm{ml}$ reagent TBA. Numbers TBA malonaldehyde expressed in mg per kg of sample[9].

\section{RESULT AND DISCUSSION}

Analysis of randomize showed that by seasoning galangal (Alpina galanga L.) and lemograss (Cymbopogon citratus) to sausage had a very significant effect $(\mathrm{P}<0.01)$ on antioxidant activity. There is an interaction between them.

Table 1: Antioxidant Activity Value (\%) of sausage by giving different types of preparations and local spice levels.

\begin{tabular}{|c|l|l|l|l|}
\hline \multirow{2}{*}{ Type of seasoning } & \multicolumn{3}{|c|}{ Seasoning of galagal and lemograss level (\%) } & \multicolumn{1}{|c|}{ Average } \\
\cline { 2 - 5 } & 0 & 5 & $63,11 \pm 4,39$ & 15 \\
\hline Stir-fry & $53,49 \pm 5,24$ & $62,50 \pm 1,11$ & $80,00 \pm 3,67$ & $64,77 \pm 10,54^{\mathrm{x}}$ \\
\hline fresh & $52,33 \pm 1,43$ & $60,02 \pm 2,12$ & $62,14 \pm 0,69$ & $65,86 \pm 2,45$ \\
\hline Average & $52,91 \pm 3,49^{\mathrm{a}}$ & $61,26 \pm 2,03^{\mathrm{b}}$ & $62,63 \pm 2,86^{\mathrm{b}}$ & $72,93 \pm 8,23^{\mathrm{c}}$ \\
\hline
\end{tabular}

Information: Different superscripts in the same column or row show significant differences $(\mathrm{P} \leq 0.01)$.

The addition of seasoning were significantly $(\mathrm{P}<0.01)$ increase the DPPH value of sausage. DPPH value showed antioxidant activity in inhibiting oxidation. This ability is very useful in preventing sausage damage. The high antioxidant activity of the sausages with the addition of seasoning (AlpinaGalanga L. andCymbopogoncitratus) because of the high content of flavonoids and phenols. AlpinaGalanga L. and Cymbopogoncitratuscontaining three active compounds of flavonoidsthat act as antioxidants. Component compound bioactive in AlpinaGalanga L. andCymbopogoncitratuswhich flavonoid compounds, kaempferol-3-rutinoside and kaempferol-3-3 oliucronide and other common components, such as amino acids, carbohydrates and acids palmitate which are relatively very small[10].

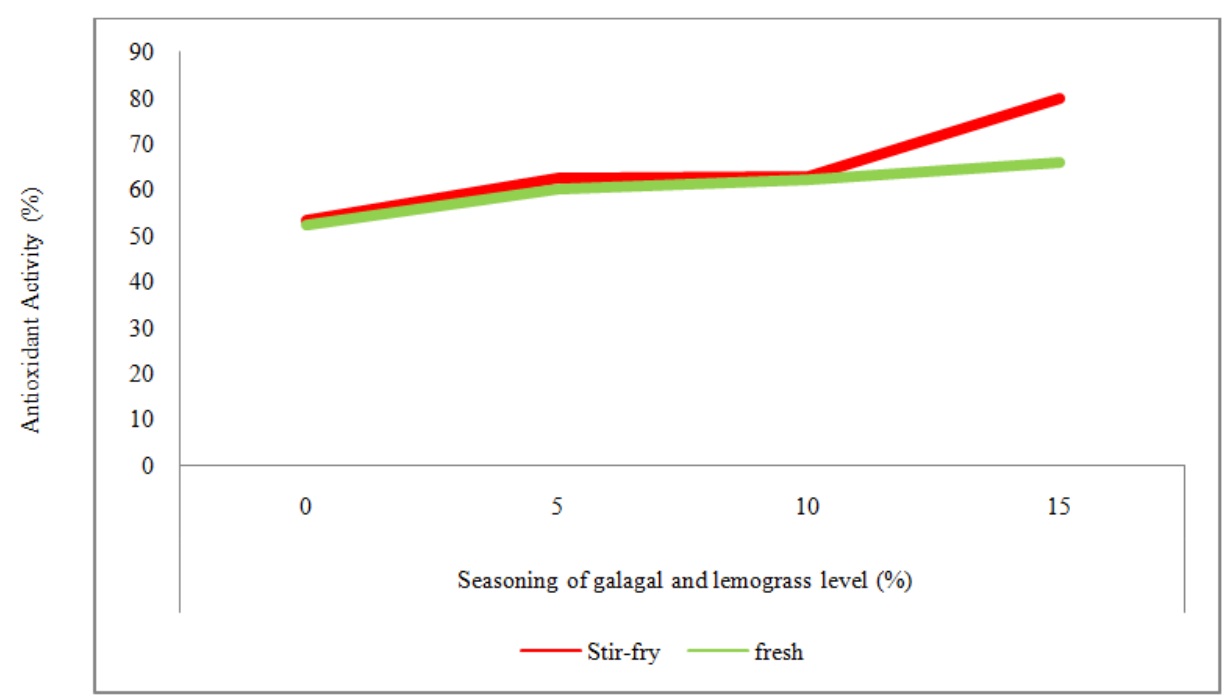

Fig. 1: Interaction between the types of seanoning and the level of addition of different spices to the antioxidant activity of sausages.

The antioxidant activity of lemongrass-galangal is high due to the content of flavonoids and phenols it contains [11. There is a high correlation between total phenol and antioxidant activity, total phenol which plays a major role in contributing to antioxidant activity. High phenol levels will increase the availability of hydroxyl groups capable of trapping radicals [12].The results of the research (Figure 1)showed that there was an interaction (P<0.01) between the type of seasoning and the level of seasoning given to antioxidant activity. Sausages with the addition of different herbs have increased antioxidant activity along with the addition of spices.Based on research conducted by [13] it was found that the antioxidant concentration in free-range chicken egg was higher than that of broiler because of its high protein content, but this resulted in lower antioxidant activity. The group of phenols and double bonds determine the concentration produced from antioxidants.

Analysis of randomize showed that by sseasoning galangal (Alpina galanga L.) andlemograss (Cymbopogon citratus) to sausage had a very significant effect $(\mathrm{P}<0.01)$ on value TBA. There is an interaction between them.

Table 2: TBA Value (\%) of sausage by giving different types of preparations and local spice levels.

\begin{tabular}{|c|l|l|l|l|}
\hline \multirow{2}{*}{ Type of seasoning } & \multicolumn{3}{|c|}{ Seasoning of galagal and lemograss level (\%) } & \\
\cline { 2 - 5 } & 0 & 5 & 10 & 15 \\
\hline Stir-fry & $0,15 \pm 0,00$ & $0,14 \pm 0,00$ & $0,12 \pm 0,00$ & $0,07 \pm 0,00$ \\
\hline fresh & $0,15 \pm 0,00$ & $0,14 \pm 0,01$ & $0,08 \pm 0,00$ & $0,08 \pm 0,00$ \\
\hline Average & $0,15 \pm 0,00^{\mathrm{c}}$ & $0,14 \pm 0,01^{\mathrm{c}}$ & $0,10 \pm 0,02^{\mathrm{b}}$ & $0,12 \pm 0,03^{\mathrm{x}}$ \\
\hline
\end{tabular}

Information: Different superscripts in the same column or row show significant differences $(\mathrm{P} \leq 0.01)$.

The level of addition of seasoning is very significant $(\mathrm{P}<0.01)$ to the value TBA sausages TBA value gets smaller in line with increasing added level seasoning of lemongrass-galangal. The addition of materials that function as antioxidants capable of inhibiting the oxidation of fat by the oxygen on the sausages so that the resulting TBA value does not exceed the specified threshold [13,14].. Antioxidants capable of slowing or prevent the oxidation of which radicals tend to react with antioxidants than with other molecules $[15,16]$. The results of the research (Figure 2 ) showed that there was an interaction $(\mathrm{P}<0.01)$ between the type of seasoning and the level of seasoning given to the level of sausage fat oxidation. These results mean that the addition of different herbs and levels influence each other on fat oxidation. The level of fat oxidation decreases with increasing local seasoning levels. Antioxidant have variety mechanisms which is radical scavenging, link metals, enzymes inhibition, lipid oxidation and pull of single oxygen [15,16]. Other antioxidant capabilities include controlling lipid levels in blood and being anti-mutagenic, having anti-inflammatory and anti-diabetic activities, etc [17,18]. 


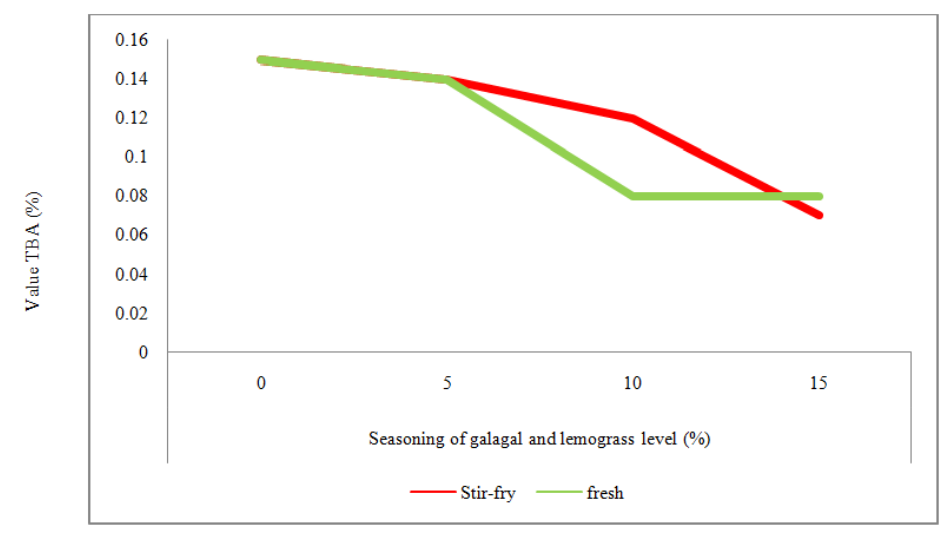

Fig. 2: Interaction between the types of seanoning and the level of addition of different spices to the value TBA of sausages.

\section{Conclusion:}

The addition seasoning of galangal-lemograss can increase the antioxidant activity seen with the high value of DPPH and low value of TBA of the sausages.

\section{ACKNOWLEDGEMENT}

The authors would like to thank the Rector of University of Hasanuddin, Prof. Dr. Dwia Aries Tina Pulubuhu M.A. and Post Graduate Program of Animal Science Department, University of Hasanuddin. And also thanks to author's supervisor and co-supervisor. Other thanks to the technicians in the Meat and Egg Laboratory University of Hasanuddinfor chemical and thanks to the Poultry Laboratory Assistant Team, University of Hasanuddin for making research samples.

\section{REFERENCES}

[1] Davidek, J., J. Vellisek and J. Pokorny, 2004. Chemical change during food processing. department of food chemistry and analysis. Institute Chemical Technology, New York.Diet Supleme. Trubus Agriwidya: Jakarta.

[2] Ridwanto, I., 2003. Nutritional content and palatability of beef sausage with substitution of broiler's cartilage flour as filler. Faculty of Animal Husbandry. Bogor Agricultural Institute, Bogor.

[3] Mapiye, C., N. Aldai, T.D. Turner, J.L. Aalhus, D.C. Rolland, J.K.G. Kramer, 2012. The Labile Lipid Fraction of Meat: From Perceived Disease and Waste to Health and Opportunity, Meat Science, 92: 210-220.

[4] Anita, S., 2009. Study of Physico-Chemical Properties, Functional Properties of Carbohydrates, and Antioxidant Activity of Coma Bean Sprouts Flour (Lablab purpureus (L.) sweet). Thesis. Bogor Agricultural Institute. Bogor.

[5] Herowati, R., 2005.Routine Anti-Inflammatory Activity and Quercetin after Oral Use of Inflammation of Karagenic Mice Feet, Journal of Indonesian Pharmacy. Surakarta, 2(1): 35-37.

[6] Singh, P., R. Shukla, B. Prakash, A. Kumar, S. Singh, P.K. Mishra and N.K. Dubey, 2010. Chemical profile, antifungal, ant aflatoxigenic and antioxidant activity of citrus maxima burm. and citrus sinensis (L.) osbeck essential oils and their cyclic monoterpene, DL-limonene. Food and Chemical Toxicology 48: $1734-1740$.

[7] Kochhar, S.P. and B. Rossell, 1990. "Detection Estimation and Evaluation of Antioxidant in Food System, editor: B.J.F. Hudson, Food Antioxidants, Elsevier Applied Science, London, 2.

[8] Miyake, T. and S. Shibamoto, 1997. "Antioxidant Activities of Natural Compounds Found in Plants", J. Agric. Food. Chem, 45: 1819-1822.

[9] Gasic, U., S. Keckes, D. Dabic, J. Trifkovic, D.M. Opsenica, M. Natie and Z. Tesic, 2014. Phenolic Profile and Antioxidant Activity of Serbian Polyfroral Honeys, Food Chem., 145: 599-607.

[10] Apriyantono, A., Analisis Pangan, 1989. Pusat Antar Universitas Pagan dan Gizi IPB, Bogor, 51.

[11] Susilaningsih, R., 2006. "Isolasi, Identifikasidan UjiToksisitas Senyawa Alkaloid Fraksi Etil Asetat Rimpang Lengkuas Merah (Alpiniagalanga)", Skripsi, Kimia Fakultas MIPA Universitas Diponegoro, Semarang.

[12] Windono, T., S. Soediman, U. Yudawati, E. Ermawati, A. Srielita, T.I. Dan Erowati, 2001. "Uji Peredam Radikal Bebas Terhadap 1,1-Diphenyl-2picrylhydrazyl (DPPH) dariEkstrak Kulit Buahdan Biji Anggur (Vitisvinifera L.) Probolinggo Birudan Bali”, Artocarpus, Surabaya, 1(1): 34-43.

[13] Windono, T., R. Budiono, Ivone, S. Valentina, Y. Dan Saputro, 2004. "Studi Hubungan Struktur Aktivitas Kapasitas Peredaman Radikal Bebas Senyawa Flavonoid Terhadap 1,1-Diphenyl-2-Picrylhydrazyl (DPPH)", Artocarpus, Surabaya, 4(2), 47-51 .

[14] Nahariah, A.M., Legowo, E. Abustamdan, A. Hintono, 2014. Antioxidant Activity and Antihypertension of "Pan Drying" White Flour Egg at Different Temperatures and Drying Times. National Seminar on Optimization of Local Resources in Technology-Based Citizen Farms. Animal Science Faculty of University of Hasanuddin. Makassar.

[15] Vankar, P.S., V. Tiwari, L.W. Singh, N. Swapana, 2006, "Antioxidant Properties of Some Exclusive Species of Zingiberaceae Family of Manipur", EJEAFChe, 5(2): 1318-1322.

[16] Pratt, D.E., 1992, "Natural Antioxidants From Plant Material", editor: M.T. Huang, C.T. Ho, dan C.Y. Lee, Phenolic Compounds in Food and Their Effects on Health H, American Society, Washington DC, 5-6.

[17] Suratmo, Reaksi Radikal Bebasdengan Suatu Materi, 2012. Fakultas MatematikadanIlmu Pengetahuan Alam Universitas Brawijaya, Malang, 30.

[18] Cos, P., T. De Bruyne, N. Hermans, S. Apers, D. VandenBerghe and A.J. Vlietinck, 2003. Proanthocyanidins in Health Care:Current and New Trends.Curre.Current Medicinal Chemistry, 10: 1345-1359.

[19] Salih, N.M., Z.S. Lazim and R.J. Kadim, 2017. Quantification of phenols and antioxidant activity for Iraqi walnut husk. American-Eurasian Journal of Sustainable Agriculture, 11(3): 14-19.

[20] Seal, T., 2016. Quantitative HPLC analysis of phenolic acids, flavonoids and ascorbic acid in four different solvent extracts of two wild edible leaves, Sonchusarvensis and Oenanthelinearis of North-Eastern region in India . J. App. Pharm. Sci., 6 (02): 157-166.

[21] Kavak, Dilek Demirbuker, 2017. Optimization of extraction time, temperature and solvent concentration for the antioxidant activity and total phenolic content of the CydoniaoblongaMill. Leaves. American-Eurasian Journal of Sustainable Agriculture, 11(6): 1-16. 